\title{
Pengaruh Frekuensi dan Periode Pemberian Pakan terhadap Bobot Relatif Organ Limfoid Ayam Buras Super
}

\author{
Effect of Frequency and Feeding Period of Crossbred Native Chicken on Relative Weight of \\ Limfoid Organs
}

\author{
Ahmat Ikhsan Arfanda*, Edjeng Suprijatna, dan Isroli \\ Fakultas Peternakan dan Pertanian Universitas Diponegoro, Semarang \\ * Corresponding e-mail: ikhsandoto@gmail.com
}

\begin{abstract}
This study aims to determine the times when chickens need feed through improved feed management with frequency $(\mathrm{F})$ and period $(\mathrm{P})$ feeding. This study used 252 super 1 day old free-range chickens with an average initial weight of $37.88 \pm 1.89$ grams. The feed used is commercial feed. The study used a split plot design, where the main plot was in the form of frequency of feeding (1 time / day, 2 times / day and 3 times / day) and sub-plot was in the form of feeding period (14 hours, 16 hours and 18 hours) so that there were 36 treatment combinations altogether. The parameters measured include the relative weight of lymphoid organs (thymus, spleen, bursa of fabricius and liver). The data obtained were observed diversity at $5 \%$ level. The results of the study showed that there was no effect of frequency and feeding period on the relative weights of the spleen, thymus and the fissile exchanges. The conclusion of this study is that the frequency and period of feeding did not increase the relative weight of lymphoid organs.
\end{abstract}

Key words : feeding frequency, lymphoid organ, Supe chicken

\begin{abstract}
ABSTRAK
Penelitian ini bertujuan untuk mengetahui waktu-waktu dimana ayam membutuhkan pakan melalui perbaikan manajemen pakan dengan frekuensi $(\mathrm{F})$ dan periode $(\mathrm{P})$ pemberian pakan. Penelitian ini menggunakan 252 ekor ayam buras super umur 1 hari dengan bobot awal rata - rata 37,88 $\pm 1,89$ gram. Pakan yang digunakan adalah pakan komersil. Penelitian menggunakan rancangan split plot, dimana main plot berupa frekunsi pemberian pakan (1 kali/hari, $2 \mathrm{kali} / \mathrm{hari}$ dan $3 \mathrm{kali} / \mathrm{hari})$ dan sub plot berupa periode pemberian pakan (14jam, 16jam dan 18jam) sehingga seluruhnya terdapat 36 kombinasi perlakuan. Parameter yang diukur meliputi bobot relatif organ limfoid (timus, limpa, bursa fabricius dan hati). Data yang diperoleh diamati keragamannya pada taraf $5 \%$.Hasil penelitian menunjukan bahwa tidak ada pengaruh frekuensi dan periode pemberian pakan terhadap bobot relatif limpa, timus dan bursa fabrisius. Kesimpulan penelitian ini bahwa frekuensi dan periode pemberian pakan tidak meningkatkan bobot relatif organ limfoid.
\end{abstract}

Kata kunci: Frekuensi pemberian pakan, organ limfoid, ayam buras super

\section{PENDAHULUAN}

Indonesia merupakan negara dengan iklim tropis, dimana suhu lingkungan yang berfluktuasi dapat mempengaruhi kondisi fisiologis ternak, saat suhu diluar comfort zone dapat mengakibatkan cekaman pada ternak. Iklim tropis pada suhu tertinggi mencapai $32,2{ }^{0} \mathrm{C}$ pada pukul $12.00-13.00$ dan suhu terendah mencapai $19{ }^{0} \mathrm{C}$ pada pukul 05.00-06.00 (Hafni et al., 2015). Suhu nyaman untuk ayam buras di daerah tropis diperkirakan berkisar antara $18-25{ }^{0} \mathrm{C}$ (Gunawan dan Sihombing, 2004). Berdasarkan suhu yang berfluktuasi maka perbaikan manajemen pakan perlu dilakukan.
Pola konsumsi ayam dipengaruhi oleh kondisi lingkungan sehingga pemberian pakan dilakukan ketika nafsu makan tinggi dengan memperhitungkan frekuensi dan periode pemberian pakan. Frekuensi pemberian pakan didasarkan pada temperatur tinggi tapi tidak kontinyu. Frekuensi pemberian pakan 1 kali, 2 kali dan 3 kali dan disesuaikan dengan fluktuasi suhu pada pagi, siang dan sore hari sehingga diharapkan pakan diberikan ketika kondisi comfort zone. Suhu lingkungan yang tinggi $\left(32,2-37,8^{\circ} \mathrm{C}\right)$ berdampak negatif pada penurunan konsumsi ransum sebesar $9,9 \%$ per ekor/hari sehingga salah satu solusi untuk mencegah heat stress yaitu diperlukan pendekatan thermal 
conditioning atau pengaturan pemberian ransum pada suhu thermoneutral zone (TNZ) ayam (Syafwan et al., 2011).

Periode pemberian pakan didasarkan pada rentang waktu akses pakan ayam dalam mengkonsumsi ransum selama 24 jam dimana pembatasan akses pakan dilakukan dengan mematikan pencahayaan. Sejak bulan Juni 2010 telah ditetapkan bahwa salah satu pengaturan animal walfare untuk ayam pedaging adalah pemberian cahaya untuk akses pakan dalam sehari tidak lebih dari 18 jam dan berdasarkan pada penelitian terdahulu diketahui bahwa periode 18 jam per hari mampu meningkatkan efisiensi penggunaan ransum (El Sabry et al., 2015). Periode pemberian pakan juga berkaitan dengan heat stress. Semakin panjang periode pemberian pakan dapat memberikan kesempatan ayam makan lebih lama sebelum terjadi peningkatan suhu di siang hari. Pada kondisi nyaman dapat mengakibatkan konsumsi ransum meningkat dan penggunaan ransum efisien, tapi saat terjadi cekaman panas ayam akan mengurangi konsumsi ransum serta penggunaan ransum jadi tidak efisien karena digunakan untuk pengeluaran panas tubuh.

Temperatur lingkungan yang tinggi dapat mempengaruhi akses ayam terhadap pakan sehingga akan berpengaruh terhadap tingkat kesehatan dan perkembangan organ limfoid pada ayam. Bobot dari organ limfoid ayam seperti timus dan bursa fabrisius dapat mengalami penurunan akibat heat stress. Hal itu dapat terjadi karena pengurangan konsumsi pakan akibat ayam terkena cekaman panas sehingga berkurangnya deposisi nutrien (Bartlett and Smith, 2003;
Hassan et al., 2007, Han et al., 2010). Bursa fabrisius dan limpa merupakan salah satu organ limfoid yang ternyata sangat dipengaruhi oleh adanya hormon kortikosteron. Ternak yang menderita cekaman panas biasanya kandungan hormon kortikosteronnya akan meningkat. Peningkatan kortikosteron tersebut dimaksudkan antara lain untuk merangsang terjadinya perombakan (katabolisme) protein sebagai usaha penyediaan glukosa darah melalui sistem glukoneogenesis sehingga terjadi penurunan pertumbuhan. Turunnya bobot bursa fabrisius dan limpa dapat menurunkan jumlah limfosit sehingga antibodi antara lain gama globulin yang penting dalam sistem kekebalan dalam tubuh ayam menjadi rendah (Kusnadi, 2008).

Penelitian ini bertujuan untuk mengetahui kombinasi antara frekuensi dan periode pemberian pakan yang optimal untuk pemeliharaan ayam buras super. Manfaat dari penelitian ini adalah memberikan informasi kepada para peternak dan masyarakat mengenai frekuensi dan periode pemberian pakan yang tepat guna untuk meningkatkan produktivitas ayam buras super.

\section{MATERI DAN METODE}

Materi yang digunakan pada penelitian ini 252 ekor ayam buras super (unsexed), dengan kandang lantai bilah yang berukuran $1,5 \times 0,75 \mathrm{~m}$ dibagi menjadi 36 unit, masing-masing unit berisi 7 ekor ayam. Pakan yang digunakan yaitu pakan komersil (Starter dan Finisher). Penelitian dilakukan selama 12 minggu.

Tabel 1. Perlakuan frekuensi dan periode pemberian pakan

\begin{tabular}{clll}
\hline \multirow{2}{*}{ Frekuensi } & \multicolumn{3}{c}{ Periode } \\
\cline { 2 - 4 } & \multicolumn{1}{c}{ P1 } & \multicolumn{1}{c}{ P2 } & \multicolumn{1}{c}{ P3 } \\
\hline FI & 08.00 & 06.00 & 04.00 \\
F2 & 08.00 dan 17.00 & 06.00 dan 17.00 & 04.00 dan 17.00 \\
F3 & $08.00,14.00$ dan 17.00 & $06.00,14.00$ dan 17.00 & $04.00,14.00$ dan 17.00 \\
\hline
\end{tabular}

Penelitian menggunakan Rancangan Acak Lengkap (RAL) dengan model Split Plot Design dengan 2 faktor perlakuan yaitu
3 taraf frekuensi pemberian pakan sebagai main plot dan 3 taraf periode pemberian pakan sebagai sub plot dalam 4 ulangan, 
sehingga terdapat 36 unit percobaan. Faktor $\mathrm{F}$ : Frekuensi pemberian pakan (1x/hari, $2 \mathrm{x} /$ hari dan $3 \mathrm{x} /$ hari). Faktor $\mathrm{P}$ : Periode pemberian pakan (14 jam, 16 jam dan 18 jam).

Tahap pengambilan data dilakukan pada akhir pemeliharaan pada umur 12 minggu dengan mengambil 1 ekor ayam sehingga total 36 unit sampel. Parameter yang diamati yaitu bobot relatif timus, bobot relatif limpa dan bobot relatif bursa fabrisius, yamg sebelumnya ayam dipuasakan 8 jam, kemudian menyembelih ayam, mencabut bulu, memisahkan antara karkas dengan organ lomfoid, mengeluarkan isi organ limfoid, menimbang bobot organ limfoid dengan menggunakan timbangan analitik dengan tingkat ketelitian 0,01 . Bobot relatif organ limfoid ayam ditentukan dengan rumus:

$$
\begin{gathered}
\text { Bobot Relatif } \\
=
\end{gathered} \frac{\text { bobot organ }}{\text { bobot hidup }} \times 100 \%
$$

\section{HASIL DAN PEMBAHASAN}

Data bobot relatif limpa, timus, bursa fabrisius dan hati ayam buras super dengan perlakuan frekuensi dan periode pemberian pakan disajikan pada Tabel 2. Berdasarkan data penelitian pada Tabel 2, bahwa konsumsi ransum untuk masing - masing perlakuan berkisar 3.192,87 - 3.547,82 g/ekor. Seperti hasil penelitian Fatma (2015) bahwa rata - rata konsumsi ransum ayam buras super dengan pemeliharaan $3-12$ minggu sebesar 3.316,19 g/ekor.

Tabel 2. Rata - rata konsumsi ransum ayam buras Super (umur 3 - 12 minggu)

\begin{tabular}{|c|c|c|c|c|}
\hline Perlakuan & $\begin{array}{c}\mathrm{P} 1 \\
14 \mathrm{jam} \\
(08: 00-22: 00)\end{array}$ & $\begin{array}{c}\mathrm{P} 2 \\
16 \mathrm{jam} \\
(06: 00-22: 00)\end{array}$ & $\begin{array}{c}\mathrm{P} 3 \\
18 \mathrm{jam} \\
(04: 00-22: 00)\end{array}$ & Rata-rata \\
\hline & & -- g/ekor ----- & 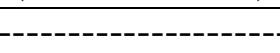 & - \\
\hline F1 (1 kali) & $3.498,46$ & $3.547,82$ & $3.455,57$ & $3.500,61$ \\
\hline F2 (2 kali) & $3.351,72$ & $3.476,34$ & $3.238,83$ & $3.355,63$ \\
\hline F3 (3 kali) & $3.402,93$ & $3.192,87$ & $3.199,43$ & $3.265,08$ \\
\hline Rata-rata & $3.417,70$ & $3.405,67$ & $3.297,94$ & \\
\hline
\end{tabular}

Tabel 3. Rataan bobot relatif limpa, timus, bursa fabrisius dan hati ayam buras Super.

\begin{tabular}{|c|c|c|c|c|}
\hline \multirow{2}{*}{ Variabel } & \multirow{2}{*}{ Frekuensi } & \multicolumn{3}{|c|}{ Periode } \\
\hline & & $\mathrm{P} 1$ & $\mathrm{P} 2$ & $\mathrm{P} 3$ \\
\hline \multicolumn{5}{|c|}{ 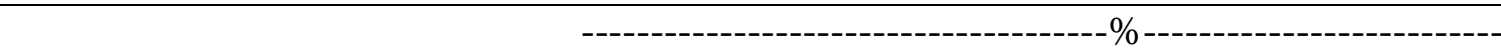 } \\
\hline \multirow{3}{*}{ Bobot Relatif Limpa } & $\mathrm{F} 1$ & 0,22 & 0,22 & 0,22 \\
\hline & $\mathrm{F} 2$ & 0,22 & 0,21 & 0,20 \\
\hline & F3 & 0,22 & 0,22 & 0,22 \\
\hline \multirow{3}{*}{ Bobot relatif timus } & F1 & 0,19 & 0,19 & 0,17 \\
\hline & $\mathrm{F} 2$ & 0,19 & 0,18 & 0,22 \\
\hline & $\mathrm{F} 3$ & 0,20 & 0,18 & 0,19 \\
\hline \multirow{3}{*}{$\begin{array}{l}\text { Bobot relatif Bursa } \\
\text { Fabrisius }\end{array}$} & F1 & 0,19 & 0,18 & 0,19 \\
\hline & $\mathrm{F} 2$ & 0,18 & 0,19 & 0,17 \\
\hline & $\mathrm{F} 3$ & 0,17 & 0,20 & 0,18 \\
\hline \multirow{3}{*}{ Bobot relatif hati } & F1 & 1,87 & 1,85 & 1,85 \\
\hline & $\mathrm{F} 2$ & 1,86 & 1,85 & 1,85 \\
\hline & $\mathrm{F} 3$ & 1,85 & 1,86 & 1,88 \\
\hline
\end{tabular}


Jumlah konsumsi ransum dipengaruhi oleh faktor fisiologis. Konsumsi ransum yang tinggi terjadi akibat ayam berada pada keadaan nyaman dan tidak mengalami heat stress yang berkepanjangan. Dari tabel 2 dapat disimpulkan bahwa konsumsi ransum ayam pada saat penelitian tergolong normal, sehingga tidak nutrien untuk kehidupan pokok dan perkembangan tercukupi yang tidak berpengaruh terhadap organ limfoid ayam tersebut.

Berdasarkan data penelitian pada Tabel 3 bobot relatif limpa, timus dan bursa fabrisius tidak berbeda nyata. Hasil penelitian menunjukan bahwa bobot relatif limpa 0,20-0,22\%, bobot relatif timus 0,17 $0,22 \%$ dan bobot relatif bursa fabrisius 0,17 $0,20 \%$. Hasil ini sama dengan hasil dari penelitian (Hassan et al., 2009; Retnani et al., 2009; Filho et al., 2010; Hwangbo et al., 2013; Jamilah et al., 2013) bahwa bobot relatif limpa ayam 0,20-0,26\% dari bobot hidup, bobot relatif timus $0,17-0,22 \%$ bobot hidup dan bobot relatif bursa fabrisius 0,20$0,22 \%$ bobot hidup.

Dari penelitian ini dapat dijelaskan bahwa ayam buras super yang diberi pakan kapanpun dan frekuensi berapa kalipun tidak mengalami stress sehingga bobot relatif organ limfoid tidak berubah. Limpa merupakan organ limfoid sekunder yang meresponsif terhadap stimulasi antigen dan mendegradasi sel darah yang sudah tua. Aktivitas limpa dapat mengakibatkan bobot limpa membesar atau bahkan mengecil karena limpa terserang penyakit atau benda asing (Indarto et al., 2011). Periode pembatasan akses pakan tidak berpengaruh terhadap bobot limpa. Hal ini sesuai dengan pendapat Yang et al., (2015) yang menyatakan bahwa pembatasan periode akses pakan dengan cara intermitten lightning program tidak memberi pengaruh yang nyata terhadap bobot limpa pada ayam. Hal ini dikarenakan ayam mampu beradaptasi terhadap periode akses pakan dan menyesuaikan jumlah konsumsinya dengan cara memaksimalkan kapasitas tembolok saat dapat mengakses pakan sehingga kebutuhan nutrisi tercukupi sehingga organ dalam kondisi sehat.

Faktor yang dapat mempengaruhi perkembangan dan ukuran bursa fabrisius diantaranya adalah asupan nutrisi, umur, infeksi dan suhu. Pakan menyediakan nutrisi untuk pertumbuhan dan perkembangan organ limfoid primer (Bursa fabrisius dan Timus) dan sekunder (Limpa, mucose associated lymphoid tissue, kelenjar limphe) (Ullah et al., 2012). Aengwanich (2008) menyatakan secara umum bursa fabrisius pada ayam yang mendapat cekaman panas menjadi atropi dan jumlah limfositnya menurun. Fenomena ini disebabkan oleh ayam yang dipelihara pada temperatur lingkungan tinggi, kortikosteron yang berasal pada adrenal kortek akan masuk kedalam sirkulasi darah untuk meningkatkan metabolisme pada ayam.

Timus ayam secara anatomis terletak pada sisi kanan dan kiri saluran pernafasan (trakea). Warnanya pucat kuning kemerahmerahan, bentuknya tidak teratur dan berjumlah 3-8 lobi pada masing-masing leher. Besar timus dapat sangat bervariasi, ukuran relatif yang paling besar pada hewan yang baru lahir sedangkan ukuran absolutnya terbesar pada waktu pubertas. Setelah dewasa, timus mengalami atrofi dari parenkhima dan korteks diganti jaringan lemak. Timus yang mengalami atrofi cepat merupakan reaksi terhadap stres, sehingga hewan yang mati sesudah menderita sakit yang lama mungkin mempunyai timus yang sangat kecil Tizard (1988). Timus merupakan regulator sel $\mathrm{T}$ yang bekerja pada sel-sel primitif yang berasal dari sumsum tulang dan membuat sel-sel itu mampu secara imunologik bertindak sebagai pembentuk antibodi tubuh (Tizard, 1987). Guo et al., (2010) yang menyatakan bahwa lama waktu ayam dapat mengakses pakan tidak memberikan pengaruh terhadap bobot relatif timus pada ayam. Hal ini karena ayam pada setiap perlakuan dapat mengatur konsusmsi pakannya sehingga kebutuhannya terpenuhi. Filho et al., (2010) menyatakan bahwa menurunya konsumsi pakan dapat mengakibatkan berkurangnya nutrien sehingga ayam menjadi stress yang 
berkepanjangan yang berakibat atropi pada timus.

Frekuensi dan periode pemberian pakan yang berbeda pada penelitian ini tidak berpengaruh nyata terhadap bobot relatif limpa, timus, bursa fabrisius dan hati ayam buras super. Hal ini dikarenakan kandungan nutrien dalam ransum yang diberikan sama. Menurut pendapat Apriliyani et al., (2013) yang menyatakan bahwa temperatur lingkungan kandang yang tinggi $\left(29-30^{\circ} \mathrm{C}\right)$ pada siang hari menyebabkan ayam mengurangi konsumsi ransum untuk mencegah terjadinya produksi panas didalam tubuh agar tidak berlebih sehingga produktivitas dan ketahanan tubuh ayam tidak menurun. Hal ini menunjukan ayam pada semua perlakuan dapat mengatasi kondisi lingkungan dengan sama baiknya sehingga tidak mengalami heat stress yang ditandai dengan bobot relatif bursa fabrisius yang lebih rendah. Menurut Mujahid et al., (2007) bahwa pemberian ransum yang lebih banyak pada siang hari dapat menurunkan produktivitas ayam, karena panas yang dihasilkan dari proses metabolisme didalam tubuh setelah mengkonsumsi ransum dan panas tambahan karena temperatur lingkungan yang tinggi sehingga konsumsi ransum dan bobot badan menurun. Menurut Apriliyani et al., (2013) bahwa pemberian ransum secara terus-menerus menyebabkan rendahnya efisiensi dan produktivitas broiler.

\section{KESIMPULAN}

Berdasarkan hasil penelitian dapat disimpulkan bahwa pada perlakuan frekuensi dan periode pemberian pakan tidak meningkatkan bobot relatif organ limfoid.

\section{DAFTAR PUSTAKA}

Aengwanich, W. 2008. Pathological changes and effect of ascorbic acid on lesion scores of bursa of Fabricius in broilers under chronic heat stress. Res. J. Vet. Sci., 1: 62-66.

Apriliyani, F., N. Suthama dan H. I. Wahyuni. 2013. Rasio heterofil limfosit dan bobot relatif bursa fabrisius akibat kombinasi lama pencahayaan dan pemberian porsi ransum berbeda pada ayam broiler. Fakultas Peternakan dan Pertanian Universitas Diponegoro, Semarang. Animal Agriculture Journal, 2. (1): p 393-399.

Bartlett, J. R. and M. O. Smith. 2003. Effect of different levels of zinc on the performance and immunocompetence of broilers under heat stress. Poult. Sci. 82: 1580-1588.

Classen, H. L., C. Riddell, dan F. E. Robinson. 1991. Effects of increasing photoperiod length on performance and health of broiler chickens.British Poultry Science. 32 (1): 21-29.

El Sabry, M. I., S. Yalcin dan G. TurgayIzzetoglu. 2015. Interaction between breeder age and hatching time affects intestine development and broiler performance. Livestock Science. 157: 612-617.

Filho Q. W. M., A. Ribeiro, V. Ferraz-dePaula, M. L. Pinheiro, M. Sakai, L. R. M. Sa, A. J. P. Ferreira and J. Palermo-Neto. 2010. Heat stress impairs performance parameters, induces intestinal injury, and decreases macrophage activity in broiler chickens. Department of Pathology, and Laboratory of Ornitopathology, School of Veterinary Medicine, University of São Paulo, Brazil.

Gunawan. dan D. T. H. Sihombing. 2004. Pengaruh suhu lingkungan tinggi terhadap kondisi fisiologis dan produktivitas ayam buras. Wartazoa. $14(1): 31-38$.

Guo, Y.L., Li, W.B., Chen, J.L., 2010. Influence of nutrient density and lighting regime in broiler chickens: effect on antioxidant status and immune function. Brit. Poultry Sci. 51:222-228. 
Hafni, W., D. Pujiastuti dan W. Harjupa. 2015. Analisis variabilitas temperatur udara di daerah Kototabang periode 2003-2012. J. Fisika Unand. 4 (2) : 185-192.

Han, A. Y., M. H. Zhang, X. I. Zuo, C. F. Zhao, J.H. Feng and C. Cheng, 2010. Effect of acute heat stress on calcium concentration, proliferation, cell cycle, and interlukin-2 production in splenic lymphocytes from broiler chickens. Poult. Sci. 89: 2063-2070

Hassan, A. M., May, ABD H. ELAzeem, M. M. Hussein, M. M. Osman and Abd El-wahed. 2007. Effect of chronic heat stress on broiler chicken performance and immune system. Dept. of Animal Hygiene, Zoonoses and Animal Behaviour and Dept. of Animal Wealth Development, Faculty of Vet. Med., Suez Canal University.

Hassan, A. M., ABD H. ELAzeem and P. G. Redy. 2009. Effect of Some Water Supplements on the Performance and Immune System of Chronically HeatStressed Broiler Chicks. Department of Animal Hygiene, Faculty of Veterinary Medicine, Suez Canal University.

Hewajuli, D. A. dan Dharmayanti. 2015. Peran sistem kekebalan non-spesifik dan spesifik pada unggas terhadap newcastle disease. WARTAZOA 25 (3): 135-146.

Hwangbo, J., H. C. Choi, S. O. Park, C. M. Ryu, B. S. Park, H. K.Kang, O. S. Seo and Y. H. Choi. 2013. Diet With Soy Oil, Molasses, Methionine, Lysine and Vitamin C Improves the Growth Performance of Broiler Exposed to Extreme Heat Stress. Departement of Animal Biotechnology, Kangwon National University, Republic of Korea. Journal of Animal and Veterinary Advances. 12 (4): 464-471.
Houston, E.G., R. Nechanitzky, P.J. Fink. 2008. Cutting edge: Contact with secondary lymphoid organs drives postthymic $\mathrm{T}$ cell maturation. $\mathrm{J}$ Immunol. 181:5213- 5217.

Indarto, E., Jamhari., Zahra, F., Zuprizal dan Kustantinah. 2011. Pengaruh Penggunaan Dried Distillers Grain With Soluble (DDGS) pada Ransum Berenergi Rendah terhadap Karkas, Lemak Abdominal, dan Hati Ayam Ayam pedaging. Buletin Peternakan. 35 (2): 71-78.

Jamilah, N. Suthama, dan L. D. Mahfudz. 2013. Performa dan ketahanan tubuh broiler yang diberi pakan step down dengan penambahan asam sitrat sebagai acidifier. Fakultas Peternakan dan Pertanian, Universitas Diponegoro, Semarang. JITV 18 (4): 251-257.

Kusnadi, E. 2010. Perubahan malonaldehida hati, bobot relatif bursa fabricius dan rasio heterofil/limfosit (H/L) ayam broiler yang diberi cekaman panas. Media Peternakan, 32(2): 8187.

Syafwan, S., R. P. Kwakkel and M. W. A. Verstegen. 2011. Heat stress and feeding strategies in meat type chickens. World's Poult. Sci J. 67: 653-673.

Ullah, M. S., T.N. Pasha, Z. Ali, Saima, F.M. Khattak dan Z. Hidayat. 2012. Effects of different pre-starter dietson broiler performance, gastro intestinal tract morphometry and carcass yield. J Anim Plant Sci. 22 (3) : 570 - 575.

Yang, H., H. Xing, Z. Wang, J. Xia, B. Yan Wan, Hou and J. Zhang. 2015. Effects of Intermittent Lighting on Broiler Growth Performance, Slaughter Performance, Serum Biochemical Parameters and Tibia Parameters, Italian Journal of Animal Science. 14 (4): 684- 689. 